\title{
Intercellular C-signaling and the traveling waves of Myxococcus
}

\author{
Brian Sager ${ }^{1}$ and Dale Kaiser \\ Departments of Biochemistry and Developmental Biology, Beckman Center for Molecular and Genetic Medicine, Stanford \\ University School of Medicine, Stanford California 94305 USA
}

\begin{abstract}
Early in their development into fruiting bodies, Myxococcus xanthus cells organize themselves into dense bands that move as trains of traveling waves. C-factor, a $20-\mathrm{kD}$ cell-surface bound protein, is a short-range developmental signal molecule required for these waves. What is the role of $\mathrm{C}$-factor in the wave pattern? It is proposed that oriented collisions between cells initiate $\mathrm{C}$-signaling, which, in turn, causes individual cells to reverse their direction of gliding. Cells would move about one wavelength and then reverse. Several lines of experimental evidence support these proposals: (1) Cells that suffered a mutation in the signal transduction pathway that controls the spontaneous reversal frequency lost the ability to form waves; (2) presentation of developing cells with detergent-solubilized C-factor increased the mean frequency of single cell reversal by three-fold; and (3) fluorescently labeled cells in the waves were tracked, and it was found that they moved and reversed on linear paths along the axis of wave propagation. Similar numbers of cells were found moving in the direction of ripple propagation, and in the reverse direction, as expected. (4) Dilution of C-signaling-competent cells with $\mathrm{C}$-factor-deficient cells increased the wavelength as the probability of productive collision decreased. The waves exemplify a way that a multicellular pattern of stripes can be produced de novo, one that maintains a uniform $50-\mu \mathrm{m}$ separation between stripes over a distance as large as $1 \mathrm{~cm}$.
\end{abstract}

[Key Words: Morphogenesis; pattern formation; cell movement; chemotaxis]

Received August 26, 1994; revised version accepted October 12, 1994.

Organized cell movements often precede overt cellular differentiation. Primordial germ cells, set aside early in development, migrate long distances before they differentiate within the developing gonads (De Felici et al. 1992). The intricate movements of gastrulation lay the foundation for subsequent differentiation of endoderm, mesoderm, and ectoderm (Keller and Winklbauer 1992). Differentiation of neural crest cells follows their migration (Le Douarin 1984). Precursors of bone and connective tissue cells condense, synthesize collagen, and advance their differentiation (Wozney 1992; Kingsley 1994). Some developmentally significant movements are organized as a wave: The morphogenetic furrow, for example, sweeps across the Drosophila eye disk, initiating in its wake differentiation of the ommatidial precursors (Heberlein et al. 1993; Ma et al. 1993).

Myxococcus xanthus cells glide into aggregation centers when they are induced to develop by nutrient limitation (for review, see Shimkets 1984). As these aggregates form and enlarge, cells between them migrate in a highly organized, periodic pattern (Reichenbach 1965). This pattern consists of a series of equally spaced ridges that move as traveling waves (Fig. 1A; Shimkets and Kai-

${ }^{1}$ Present address: Center for Cancer Research, Department of Biology Massachusetts Institute of Technology, Cambridge Massachusetts 02139 USA. ser 1982). Because these waves first appear on the surface of a uniform and unstructured mat of cells, they are called ripples. Rippling outside typically precedes the differentiation of spores inside the nascent fruiting body (Reichenbach 1965), although rippling is not absolutely required for sporulation. $M$. xanthus cells have the simple structure of Gram-negative, rod-shaped bacteria. They have a total genome of 9.2 Mb (He et al. 1994) for which a wide variety of genetic tools have been developed (Gill and Shimkets 1993). These qualities open the traveling waves to cell and molecular genetic studies.

Microscopic examination of rippling waves revealed that their crests are composed of heaps of cells while the troughs between adjacent ridges contain many fewer cells (Shimkets and Kaiser 1982). By proper adjustment of nutrient levels, rippling waves can be observed to form over the entire surface of a developing mat of cells and to continue their periodic motion for days. Even after several days there is no net accumulation of cells in any region of the culture larger than one wavelength, suggesting that individual cells move in cyclic paths.

Cell-cell signaling is necessary for fruiting body development (Kroos et al. 1986, Kroos and Kaiser 1987). Mutants defective in either A- or B-signaling cannot form fruiting bodies, yet can ripple (Shimkets and Kaiser 1982). In contrast, C-factor, a $20-\mathrm{kD}$ cell envelope-associated protein encoded by the $\operatorname{csg} A$ gene, is required both 


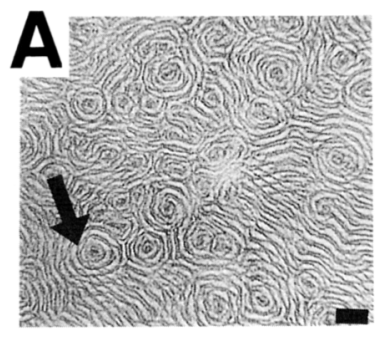

B

Figure 1. $(A)$ Rippling waves in submerged culture of wild-type cells. Ripple wavecrests are evident as dark bands of circular or linear form. Objective magnification, $1.1 \times$ Scale bar, $200 \mu \mathrm{m}$. (B) Traces of the successive shapes and positions of countermigrating wild-type ripples tracked in $A$ by time-lapse videography (arrow in $A$ depicts tracking region). Half-arrows depict direction of movement of rippling waves. Wave fronts were traced every $10 \mathrm{~min}$. Scale bar, $200 \mu \mathrm{m}$.

for fruiting body formation and for rippling (Shimkets et al. 1983; Hagen and Shimkets 1990; Kim and Kaiser 1990a; Shimkets and Rafiee 1990). Investigating the role of C-factor in the organization of ripples has led us to propose and test a model for the periodic spacing of rippling waves in which cells travel a distance equal to a ripple wavelength without reversing. Contact with countermigrating cells in a neighboring ripple then allows transmission of the C-signal, triggering cell reversals. The resulting back-and-forth movement of rippling cells explains how the waveforms could be propagated in the absence of net cell movement and provides insight into the process of $\mathrm{C}$-signal transmission.

\section{Results}

\section{Collisions of rippling waves}

When exposed to nutrient levels that limit but do not prevent growth, $M$. xanthus cells assemble high-density bands that move as traveling waves (Reichenbach 1965; Shimkets and Kaiser 1982). These waves resemble the ripples on the surface of water into which a stone has been dropped, and because they often appear as waves on the surface of a mat of $M$. xanthus cells, they are also called ripples. Ripples formed in culture can be organized as ladders of linear waves or as domains whose constituent waves form circles and appear to spread outward (Fig. 1A). Adjacent countermigrating circular waves emanating from two neighboring centers often collide with each other. Particular ripples can be identified and followed because they often have local variations in their curvature, which allows the waves to be tracked as they collide with one another (Fig. 1B). Successive traces of the wavefronts of countermigrating waves give the clear impression that two ripples interpenetrate one another without interference, that is, without buildup, depletion, or distortion at the crossover points (Fig. 1B). The perception of interpenetration without interference is strong; the shapes of asymmetric wavefronts remain unchanged as they leave an intersection. Interference be- tween ripples is also strikingly absent from the countermigrating waves at the edge of Stigmatella aurantiaca swarms, which are published as time-lapse recordings available on videotape (film E2421, Reichenbach 1980). The absence of interference is difficult to imagine because scanning electron micrographs of rippling waves of $M$. xanthus reveal that each wave crest contains a stack of cells (Shimkets and Kaiser 1982). Because cells occupy space, how can two moving stacks of cells pass through each other without interference?

\section{Orientation of cells in ripples}

Gliding cells move in the direction of their long axes (Burchard 1981). One possibility for smooth interpenetration is that cells could be gliding in some direction other than the ripple progression. If cells do not meet head on they might be able to slip past one another when two ripples collide. Scanning electron microscopic examination of the cells at the very top of ripple crests revealed a tendency of cells to be oriented at a $40^{\circ}$ angle relative to the direction of ripple migration (Shimkets and Kaiser 1982). However, the cell orientations elsewhere within a ripple have not been studied. Accordingly, the positions of cells were examined at the base of the ripples, where the cells contact the substratum on which they move. Wild-type cells (strain DK1622) were labeled with the fluorescent probe PKH-2 (Sager and Kaiser 1993a) and induced to develop by starvation on a TPM agar surface (see Materials and methods). Nine hours later, the arrangements of cells in ripples were examined by fluorescence confocal microscopy. The regular orientations of single fluorescent cells at the ripple base can be seen in Figure 2A. The many cells at the base of ripple crests and the fewer cells in the troughs between ripples were, on average, oriented at a $90^{\circ}$ angle relative to the ridge line of the ripple (Fig. $2 \mathrm{~B}$ ). At least some of these cells would be expected to meet head on when two ripples collide and thus would be expected to interfere with each other. Thus, an alternative explanation must be sought for the absence of interference.

\section{Wave propagation by reflection}

Any alternative mechanism for cell movement in the absence of ripple interpenetration should nevertheless preserve the detailed curvature of a wave, the feature that leads one to perceive interpenetration. One alternative that satisfies this condition is precise reflection. Wave topography could be conserved after intersection, if most of the cells within a wave front reverse when they come into contact with the cells in an adjacent colliding wave. Figure 3 depicts a rightward-moving ripple (R1 in Fig. 3A) contacting a leftward-moving ripple $(R 2)$. If the cells in each wave reflect one another point by point when they meet, the curvature of both waves will be maintained. As long as the cells in a wave front move with the same average velocity, the leading cells of a wave, which would be the first to reach a colliding wave, would also be the first to reverse. With reflection, wave 

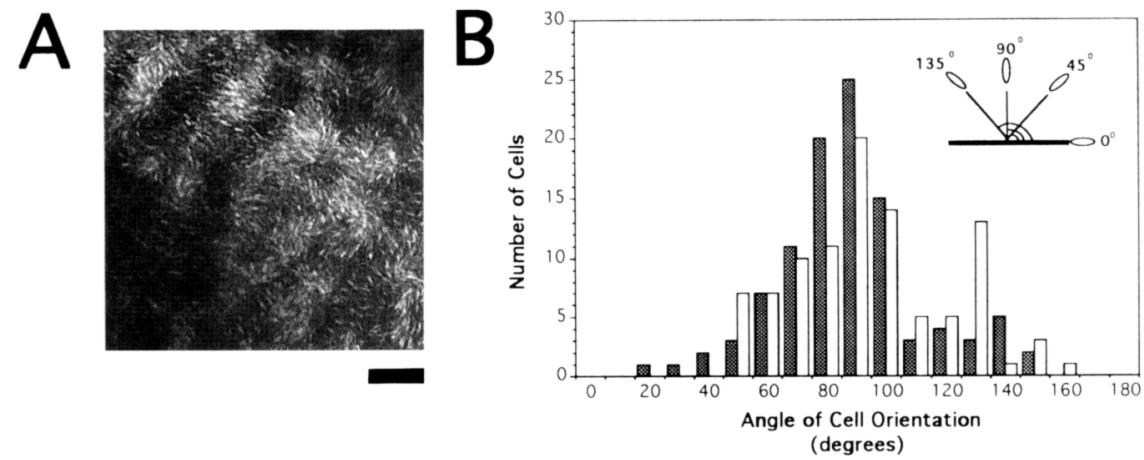

Figure 2. Orientations of cells at the base of 9-hr ripples composed of wild-type cells (strain DK1622). (A) Fluorescence confocal microscopy of PKH-2-labeled cells. Scale bar, $20 \mu \mathrm{m} .(B)$ Histogram of cell orientations at the basal focal plane. Cell orientation is defined as the angle between the long axis of a cell and the direction of ripple propagation (see inset). The angular orientations of 200 cells were scored for cells in both ripple crests (stippled bars) and ripple troughs (open bars).

fronts that are in the midst of meeting and appear continuous would actually have mixed origins, instead of a homogeneous origin (Fig. 3, cf. B and C). Consider a rightward-moving front: Up to the points of intersection, the cells would be those from the ripple field depicted by thick lines. But between the two points of intersection with a leftward-moving front, the cells would be those from the ripple field depicted by thin lines.

\section{Wave propagation depends on cell reversal}

The wave reflection model argues that cell reversal follows cell contact. Isolated wild-type $M$. xanthus cells reverse approximately once in $7 \mathrm{~min}$ (Blackhart and Zusman 1985). The frizzy (frz) mutants of $M$. xanthus inactivate genes in a phosphorelay circuit that alters this probability of reversal (McBride et al. 1989). To test the hypothesis that induced cell reversal is necessary for rippling, strains harboring mutations in the frzCD gene were examined for their ability to ripple. The frzCD gene is a homolog of the carboxy-terminal portion of the methyl-accepting chemotaxis receptor proteins of enteric bacteria. Strains harboring mutations in frzCD exhibit altered average cell reversal frequencies relative to $\mathrm{frz}^{+}$ (Blackhart and Zusman 1985; McBride et al. 1989). Transposon insertions $\Omega 536$ and $\Omega 224$ are at different sites within the coding region of the frzCD gene and generate truncated gene products (McBride et al. 1989; Weinberg and Zusman 1989). These truncations alter the signaling states of the translated proteins and change cell behavior. In particular, insertion strains $\Omega 536$ and $\Omega 224$ have hypo- and hyper-reversing single-cell behavior, re- spectively. Mutant strains bearing insertions $\Omega 536$ and $\Omega 224$ were originally isolated in an sglA1 parent strain mutant for social motility (Zusman 1982). Because rippling requires that social motility be active (Shimkets and Kaiser 1982), these insertion mutations were transduced (see Materials and methods) into strain DK1622, which has normal social motility. These transductants were checked by videomicroscopy of dilute cell cultures. Single wild-type cells (strain DK1622 $\mathrm{frz}^{+}$) were found to change direction, on average, once in $10 \mathrm{~min}$. In contrast, the insertion strain frzCD:: $\Omega 536$ (DK8505) reversed, on average, once in $100 \mathrm{~min}$, whereas the frzCD:: $\Omega 224$ (DK8506) reversed once in $2.2 \mathrm{~min}$. The mean reversal frequency observed for the insertion strain is similar to the 2-min value reported by Blackhart and Zusman (1985) in an sglA1 strain.

Examination of the $\Omega 536$ and $\Omega 224$ insertion strains under conditions that induce rippling in wild-type cells (see Materials and methods) showed that neither frz mutant was able to form ripples (Fig. 4). These data argue that improper regulation of the frequency of cell reversal disrupts rippling cell movements. Because the average ripple period is $10-15 \mathrm{~min}$, and isolated $\mathrm{frz}^{+}$cells spontaneously reverse once every $10 \mathrm{~min}$, on average, the hyporeverser (reversing once every $100 \mathrm{~min}$ ) and the hyper-reverser (reversing every $1.5 \mathrm{~min}$ ) strains evidently have inappropriate spontaneous frequencies to permit rippling. Alternatively, these mutants may have uncoupled C-signaling from cell movement.

It was also observed that the $\Omega 536$ (DK8505) and $\Omega 224$ (DK8506) insertion strains fail to form fruiting bodies in submerged culture or to produce normal levels of heat-
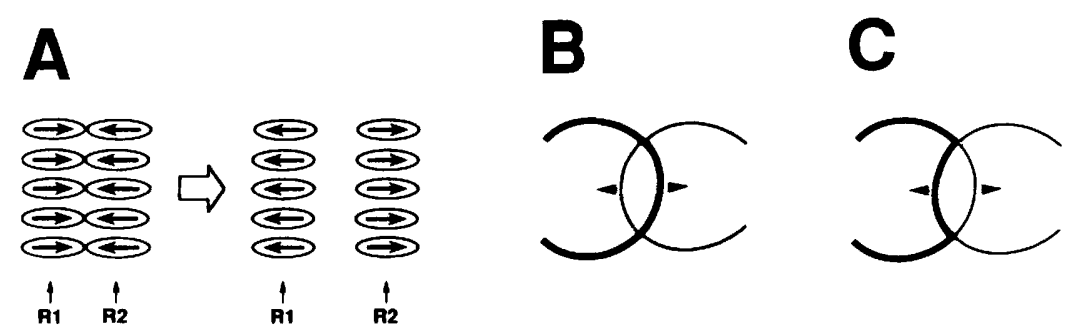

1
Figure 3. (A) A reflection model for the interaction between individual cells in two countermigrating rippling waves. Laterally aligned cells in countermigrating ripples (labeled R1 and R2) reverse upon end-to-end contact. Arrows represent the directions of cell movement. Relative cell positions are preserved. $(B)$ Morphology of ripple waves after collision. Thick and thin lines represent rightward and leftward moving wave fronts, respectively. Arrows show directions of wave movement. $(C)$ Reflection of the same waves shown in $B$, with the ripple cell lineages modified to illustrate the effect of reversal. 

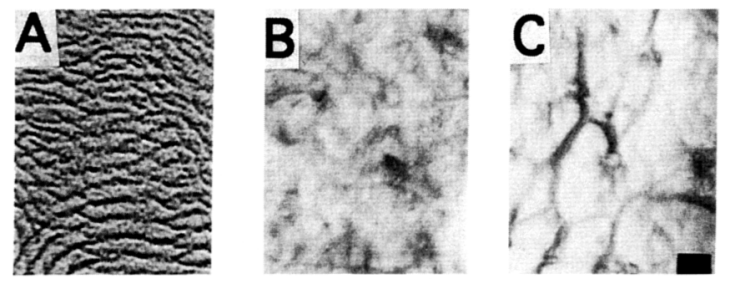

Figure 4. Capacity of wild-type and $f r z^{-}$mutant strains to form ripples. Submerged cultures after partial starvation for 48 $\mathrm{hr}$. Objective magnification is $2.5 \times$. Scale bar, $100 \mu \mathrm{m}$. $(A)$ Wild type (strain DK1622); $(B)$ hyporeversing insertion strain $\Omega 536$ (DK8505); $(C)$ hyper-reversing insertion strain $\Omega 224$ (DK8506).

and sonication-resistant spores. Whereas DK1622 $\left(\mathrm{frz}^{+}\right)$ cells produce $1 \times 10^{6}$ spores per $2 \times 10^{8}$ cells induced to develop, under similar conditions the $\Omega 536$ and $\Omega 224$ strains produce an average of $5 \times 10^{4}$ and 400 spores, respectively, per $2 \times 10^{8}$ developing cells /see Materials and methods). Thus, these $f_{r z}{ }^{-}$strains have multiple developmental defects.

\section{Control of cell reversal by C-signaling}

According to the reflection hypothesis for ripple interaction, the wave form of two colliding ripples is preserved at the level of individual cells by coordination of cell reversal when counter-moving pairs of cells within the ripples collide. These cell collisions and responses (Fig. $3 \mathrm{~A}$ ) would provide a precision of interaction that would preserve the shape of a ripple in detail. C-factor is a developmentally induced protein encoded by the $\operatorname{csg} A$ gene, which is required for intercellular signaling during development (Kroos et al. 1986; Shimkets and Asher 1988; Kim and Kaiser 1990a,b; Li et al. 1992). It is known that $\mathrm{C}$-factor is specifically required for rippling because $\operatorname{csg} A$ mutants do not ripple, whereas other intercellular signaling mutants (the asg and bsg strains) can ripple (Shimkets and Kaiser 1982). C-signaling is likely to elicit some kind of movement response, as $\operatorname{csg} A$ is required for normal aggregation (Kim et al. 1993). Might C-signaling direct cells to reverse when they collide? C-factor appears to be bound to the cell envelope because it sediments with the membrane fractions of wild-type cells and must be extracted from them with a detergent (Kim and Kaiser 1990a,b) yet can also be found near the cell surface as judged by the behavior of immunogold-labeled antibody to C-factor (Shimkets and Rafiee 1990). Moreover, extensive end-to-end and side-by-side alignment of cells restores $\mathrm{C}$-signal-dependent gene expression and sporulation to otherwise developmentally defective nonmotile cells (Kim and Kaiser 1990c; Kim 1992). In these experiments, extensive side-by-side alignment proved inadequate to rescue $\mathrm{C}$-signal-dependent gene expression or sporulation. Thus C-signaling may specifically occur between cells in end-to-end contact. End-to-end cell arrangements are common at the base of ripples (Fig. 2).

Furthermore, active C-factor can be extracted from rippling cells. C-factor activity has not been detected in cultures of growing cells (Kim and Kaiser 1990a,b), which our own assays confirm (data not shown); however, bioassay of $\mathrm{C}$-factor extracted from rippling cells cultivated for $48 \mathrm{hr}$ revealed that rippling cultures do produce $\mathrm{C}$-factor. From $0.72 \mathrm{mg}$ of protein extracted with CHAPS detergent from sonicates of rippling cultures /see Materials and methods), 45 fruiting bodies and $3.6 \times 10^{5}$ spores formed per $2.5 \times 10^{8}$ tester $\operatorname{csg} A$ cells. This developmental rescue corresponds to a sp. act. of $0.25 \mathrm{C}$-factor $\mathrm{U} / \mathrm{mg}$ of protein, since 1 unit of biological activity rescues 250 fruiting bodies and $2 \times 10^{6}$ spores per $2.5 \times 10^{8}$ tester csgA cells (Kim and Kaiser 1990a, 1990b). The specific activity of $\mathrm{C}$-factor in rippling cultures $10.25 \mathrm{U} / \mathrm{mg}$ of protein) is 100 -fold lower than that extracted from developing fruiting bodies $(25 \mathrm{U} / \mathrm{mg}$ of protein; Kim and Kaiser 1990b; B. Sager, unpubl.). This difference in specific activity may arise from the different nutritional regimes employed. Cultures are totally depleted of nutrients to induce fruiting body development ( $0 \%$ casitone), but are nutrient limited $(0.25 \%$ casitone $)$ to induce prolonged rippling.

If cell-contact-mediated C-signaling triggers cell reversals during rippling, as hypothesized, then addition of solubilized C-factor should mimic constant intercellular contact and increase the probability of reversal of gliding direction. To study the effect of C-signaling on cell movement, solubilized C-factor was added to wild-type cells (strain DK5204) previously starved for $48 \mathrm{hr}$ in submerged MC7 buffer (Kuner and Kaiser 1982) to induce development. Cell reversal frequencies of single motile rod cells that were located within $50 \mu \mathrm{m}$ of a nascent fruiting body were measured using time-lapse videomicroscopy. Cells chosen for examination had been starved and had proceeded into the aggregation phase of development. Such cells were chosen because they adhere to their substratum more strongly than either vegetative rod cells or cells developing prior to aggregation $\left(\mathrm{O}^{\prime} \mathrm{Con}\right.$ nor and Zusman 1991a; B. Sager, unpubl.). Strong adherence of the cells to the substrate permits the addition of fluid samples to submerged developing cultures without dislocating cells from their substratum and without interrupting their movement. Time-lapse vidoemicroscopy revealed that such cells repeatedly entered and exited fruiting bodies during the previous $48 \mathrm{hr}$. When inside the outer domain of a fruiting body they would have been exposed to a high density of aligned $\mathrm{C}$-signaling cells, an environment likely to induce C-signal responsiveness typical of that time of development (Sager and Kaiser 1993b). Moreover, cells outside fruiting bodies at this stage have been shown to express myxobacterial hemagglutinin (O'Connor and Zusman 1991b), which, though not yet examined for $\mathrm{C}$-signal dependence, is expressed after the earliest C-factor-dependent genes (Kroos and Kaiser 1993).

The specific activity of $\mathrm{C}$-factor derived from cells in rippling culture is 100 -fold less than that extracted from fruiting body cultures (see above). Because cells in fruiting body culture aggregate in response to 1 unit of C-factor, we hypothesized that cells in rippling culture would be responsive to a 100 -fold lower C-factor dosage. To simulate the concentration of $\mathrm{C}$-factor to which rippling 
cells might be exposed, single developing cells were challenged with $0.005,0.01,0.02,0.04$, and 0.08 units of $\mathrm{C}$-factor. Prior to addition of $\mathrm{C}$-factor, the assay cells showed a mean frequency of 0.09 reversals $/ \mathrm{min}$. Twenty minutes after addition of 0.02 units of $\mathrm{C}$-factor partially purified to a sp. act. of $60 \mathrm{U} / \mathrm{mg}$ (solubilized C-factor; see Materials and methods), the reversal frequency of the same cells had increased more than threefold to 0.32 reversals/min (Fig. 5). Cells continued to exhibit this high reversal rate for at least $1 \mathrm{hr}$ without apparent adaptation. C-factor levels of $0.01,0.04$, and 0.08 units also gave threefold increases in mean cell reversal frequency. No response was detected in cells exposed to 0.005 unit of $\mathrm{C}$-factor. Evidently the reversal response to $\mathrm{C}$-factor, like the rescue of sporulation and fruiting body development by C-factor (Kim and Kaiser 1990b), is not directly proportional to the amount of factor added. Similar to the effects of higher concentrations of C-factor on developmental rescue, 0.16 unit of the factor inhibited cell movement.

As shown in Figure 5, several experiments argue that the increase in reversal frequency detected upon addition of C-factor-containing extracts is specifically attributable to C-signaling. First, addition of 0.02 unit of C-factor at different specific activities 160 and $400 \mathrm{U} / \mathrm{mg}$ of protein) gave similar increases in reversal frequency. The similar motility effects of $\mathrm{C}$-factor extracts at different

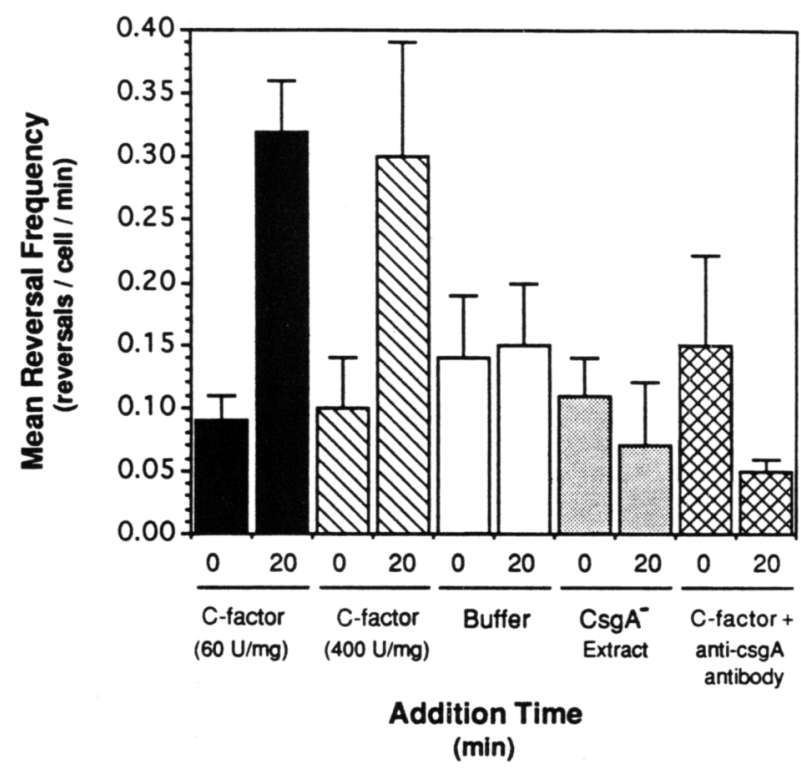

Figure 5. Effect of $\mathrm{C}$-factor addition on the mean reversal frequency of single cells moving near wild-type fruiting bodies (strain DK5204). Cultures had been developing for $48 \mathrm{hr}$ when the various additions were made. (Solid bars) Addition of 0.02 units of $\mathrm{C}$-factor $(60 \mathrm{U} / \mathrm{mg}$ ); (hatched bars) addition of 0.02 units of $\mathrm{C}$-factor (400 U/mg); (open bars) addition of $50 \mu$ l developmental buffer; (stippled bars) addition of $1.6 \mu \mathrm{g}$ of $\operatorname{csg} A^{-}$(strain DK5253) protein extract; (crosshatched bars) addition of 0.02 units of C-factor $(60 \mathrm{U} / \mathrm{mg})$ preincubated with anti-csgA antibody. Error bars represent the standard error of triplicate experiments. stages of purification argue against a motility effect attributable to a protein that does not copurify with C-factor. Second, the increase is unlikely to be a result of mechanical agitation of the developmental culture when the sample is added, as buffer addition had no effect. Third, an extract was partially purified from an isogenic $\operatorname{csg} A^{-}$strain (DK5253) using the same protocol followed for purification of C-factor to a sp. act. of 60 of C-factor $\mathrm{U} / \mathrm{mg}$ of protein (Kim and Kaiser 1990a,b; see Materials and methods). As neither fruiting bodies nor spores formed when this extract was added to $\operatorname{csg} A^{-}$cells, the $\operatorname{csg} A^{-}$extract contained no detectable C-factor activity. Consistent with the absence of $\mathrm{C}$-factor, the addition of $1.6 \mu \mathrm{g}$ of $\operatorname{csg} A^{-}$protein extract, a concentration of total protein that would be added with 0.02 unit of $\mathrm{C}$-factor, had no effect on the mean reversal frequency $\{0.02$ unit of a C-factor preparation with a sp. act. of $60 \mathrm{U} / \mathrm{mg}$ of protein contains $1.6 \mu \mathrm{g}$ of protein). Therefore, the increase in reversal frequency induced by 0.02 units of C-factor from a $\operatorname{csg} A^{+}$extract is not likely to result from the addition of protein in the extract other than $\mathrm{C}$-factor. Addition of either $\operatorname{csg} A^{-}$protein extract or BSA at a 10 -fold higher concentration $(16 \mu \mathrm{g})$ inhibited cell movement. Finally, preincubation of $\mathrm{C}$-factor containing extract with a dilute suspension $(<1 \mu \mathrm{g} / \mathrm{ml})$ of affinitypurified polyclonal anti-csg $A$ antibody eliminated the increased reversal rate. The mean reversal rate decreased after addition of antibody, suggesting that endogenous as well as exogenous $\mathrm{C}$-factor was neutralized in the cell culture.

\section{Movements of single cells within ripples}

The C-signal-induced reflection model (Fig. 3) implies that individual cells tend to oscillate back and forth while the ripple wave front appears to propagate in a given direction. To examine the movements of single cells within ripples, wild-type cells were labeled with the fluorescent marker PKH-2 (Sager and Kaiser 1993a) and mixed 1: 1000 with unlabeled cells. Cell mixtures were induced to ripple on TPM agar-coated slides, and cells at the base of the ripples were followed by timelapse fluorescence confocal video microscopy (see Materials and methods) for $40 \mathrm{~min}$, an interval much greater than the period of a ripple. At a 1:1000 ratio of labeled to unlabeled cells, the density of labeled fluorescent cells was low enough to permit the tracking of single cells within ripples (Fig. 6A). Unlabeled cells in rippling wave fronts were also visible, albeit at much weaker fluorescence intensity, as Myxococcus cells harbor endogenous autofluorescent pigments (Rosenberg 1984; Russo-Marie et al. 1993; Sager and Kaiser 1993a). We have taken advantage of the ability to simultaneously image both single cells and the position of the ripple crest to determine the cell density within the crest. The number of labeled cells per unit area was multiplied by the thickness of the confocal optical section, $0.5 \mu \mathrm{m}$, to determine the volume within which the cells resided. This value, $2 \times 10^{8}$ cells $/ \mathrm{cm}^{3}$, was multiplied by a factor of 1000 to account for the unlabeled autofluorescent cells. The cell density 
Figure 6. Movements of single cells within rippling waves detected by fluorescence labeling. A mixture composed of 1 labeled cell per 1000 unlabeled, yet (auto)fluorescent, cells was examined in a confocal microscope that had been focused on the layer of cells located at the base of a train of ripples. $(A)$ Differences in fluorescence intensity of individual cells are depicted by the gray scale. Labeled, and thus strongly fluorescent, single cells show as spots of white. Unlabeled, and thus weakly (auot)fluorescent cells show as gray spots. The parallel bands of gray spots reveal the train of adjacent ripples. Areas between ripples, having very few cells, appear black in the photograph. Microscope objective magnification, $7.5 \times$. Scale bar, $50 \mu \mathrm{m}$. (B) The paths of 76 representative strongly fluorescent (labeled) single cells have been tracked through time by the progressive displacements of their centers. The field shown in $A$ was photographed every $30 \mathrm{sec}$ for $40 \mathrm{~min}$. The position of a cell at 3 -min intervals is indicated by the small circles. A small circle is filled in for the frame in which the cell reverses its direction of movement. A sequence of open circles indicates a cell that is moving in one direction. The direction of cell movement at the end of each path is represented by a half-arrow at the end point. Thick lines connecting adjacent circles indicate that a moving cell lies within the crest of a ripple. Thin lines connecting adjacent circles represent cell movement in troughs. The double-headed arrow in the upper right-hand corner of $B$ shows the axis along which the waves are moving and the train of ripples is propagating.
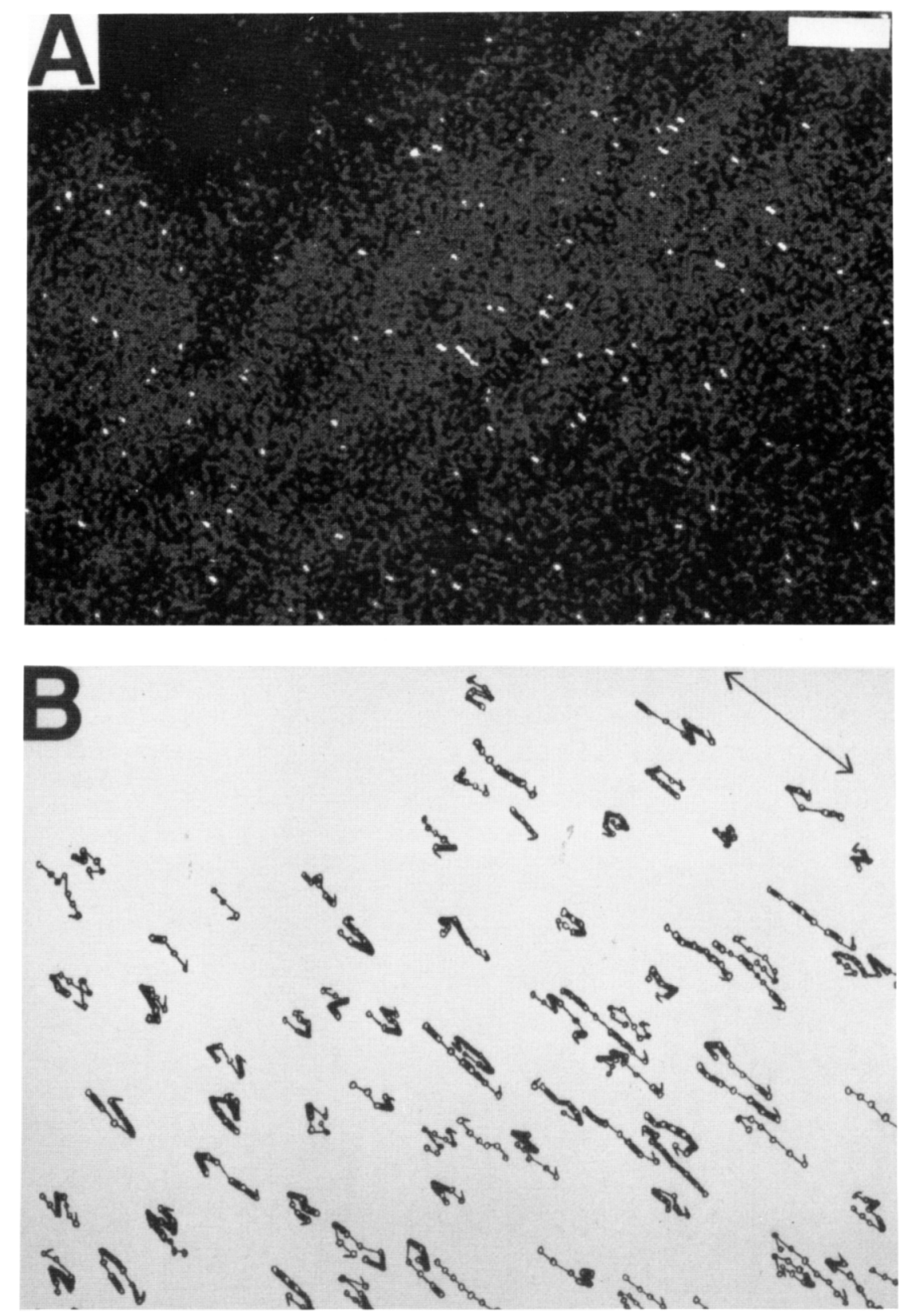

within the ripple crest is thus $2 \times 10^{11}$ cells $/ \mathrm{cm}^{3}$, a value comparable to the outer domain of the nascent Myхоcoccus fruiting body (Sager and Kaiser 1993a), where $\mathrm{C}$-signaling leads to the differentiation of spores (Sager and Kaiser 1993b). The total flourescence intensity of cells in the troughs is eightfold less than that of cells in the crest (Figs. 2 and 8 , below); thus, the density in the troughs is $\sim 2.5 \times 10^{10}$ cells $/ \mathrm{cm}^{3}$.

Figure $6 \mathrm{~B}$ depicts the trajectories of single cells moving within a system of ripples observed over a period of 40 $\mathrm{min}$. As the ripple waves in Figure 6B progress through the field, $62 \%$ of the cells alternately travel in both ripple crests and troughs. Thus, the composition of cells within a particular ripple would progressively change as the wave propagates, and the movements of individual cells is not identical with that of the ripple wavecrests. Moreover, a comparison of the 76 tracks in Figure 6B shows that cell movement is by no means stereotyped: No two cells move in exactly the same way. These observations imply that the cell waves correspond to average behavior and constraints on the motion of individual cells. Three important constraints are evident in the cell tracks. First, the paths of single cells were predominantly linear, aligned parallel to one another, and parallel to the direction of ripple wave propagation, which is indicated by the continuous double-headed arrow in the upper right corner of Figure 6B. Second, similar numbers of cells moved in the two directions indicated by the arrowhead at the end of each trajectory: $46 \%$ leftward (and upward), 54\% rightward (and downward), as ex- 
pected if their movement arises by repeated reflection and reversal (Fig. 3). Third, among the 76 cells tracked in Figure $6 \mathrm{~B}$, there are 80 reversals; 59 cells reversed at least once; 20 cells reversed twice. Reversal frequencies were measured on 100 randomly chosen labeled cells tracked in Figure 6B and another independent experiment totaling 1917 cell minutes (cell-min) of movement. Cells in ripple crests had a mean frequency of $0.081 \pm 0.009$ reversals per cell-min, a rate threefold higher than that of cells moving within troughs, which changed direction with a frequency of $0.025 \pm 0.006$ reversals per cell-min. Within the ripple crests, cells moved an average of 3.9 min before reversing. By and large the cells did not move continuously as the ripple wave propagated but, rather, reversed after traveling a distance on the order of a ripple wavelength. The boundaries of the ripple crests were not sharp enough (Figs. 2 and 8, below) to allow the time and place of ripple collision to be defined.

\section{Ripple wavelength depends on the density} of C-signaling-competent cells

If cell-contact-mediated C-signaling triggers cell reversals, which in turn maintain the traveling waves (ripples|, then changing the probability of contact between signaling cells would be expected to alter the ripple wavelength. In pure cultures of $\operatorname{csg} A^{+}$cells at high density, extensive $\operatorname{csg} A^{+}$intercellular contact would be expected to result in the typical ripple wavelength of 60 $\mu \mathrm{m}$ (see below). In cultures containing few $\operatorname{csg} A^{+}$cells, the more rare $\operatorname{csg} A^{+}$intercellular contacts should induce less frequent cell reversals and result in a longer ripple wavelength.

The probability of intercellular C-signaling was systematically decreased by mixing decreasing numbers of $\operatorname{csg} A^{+}(\mathrm{DK} 1622)$ cells with increasing numbers of $\operatorname{csg} A^{-}$ (LS202) cells while holding constant the total number of cells in the mixture. After mixing, the fraction of each cell type in the mixture should remain constant, as strains DK1622 and LS202 have similar growth rates (data not shown). The mixed cultures were then subjected to a nutrient step down to induce rippling, and the morphologies of the resulting ripples were observed by inverted bright-field microscopy and recorded by timelapse videography (Fig. 7). Pure cultures of $\operatorname{csg} A^{+}$cells were observed to have a mean ripple wavelength of 60 $\mu \mathrm{m}$ and a mean period of $6.0 \mathrm{~min}$ (Fig. 7). The crests of these waves were, on average, $7.0 \mu \mathrm{m}$ wide (equal to one cell length|, and moved with an average velocity of 8.0 $\mu \mathrm{m} / \mathrm{min}$. As the fraction of $\operatorname{csg} A^{+}$cells was reduced to
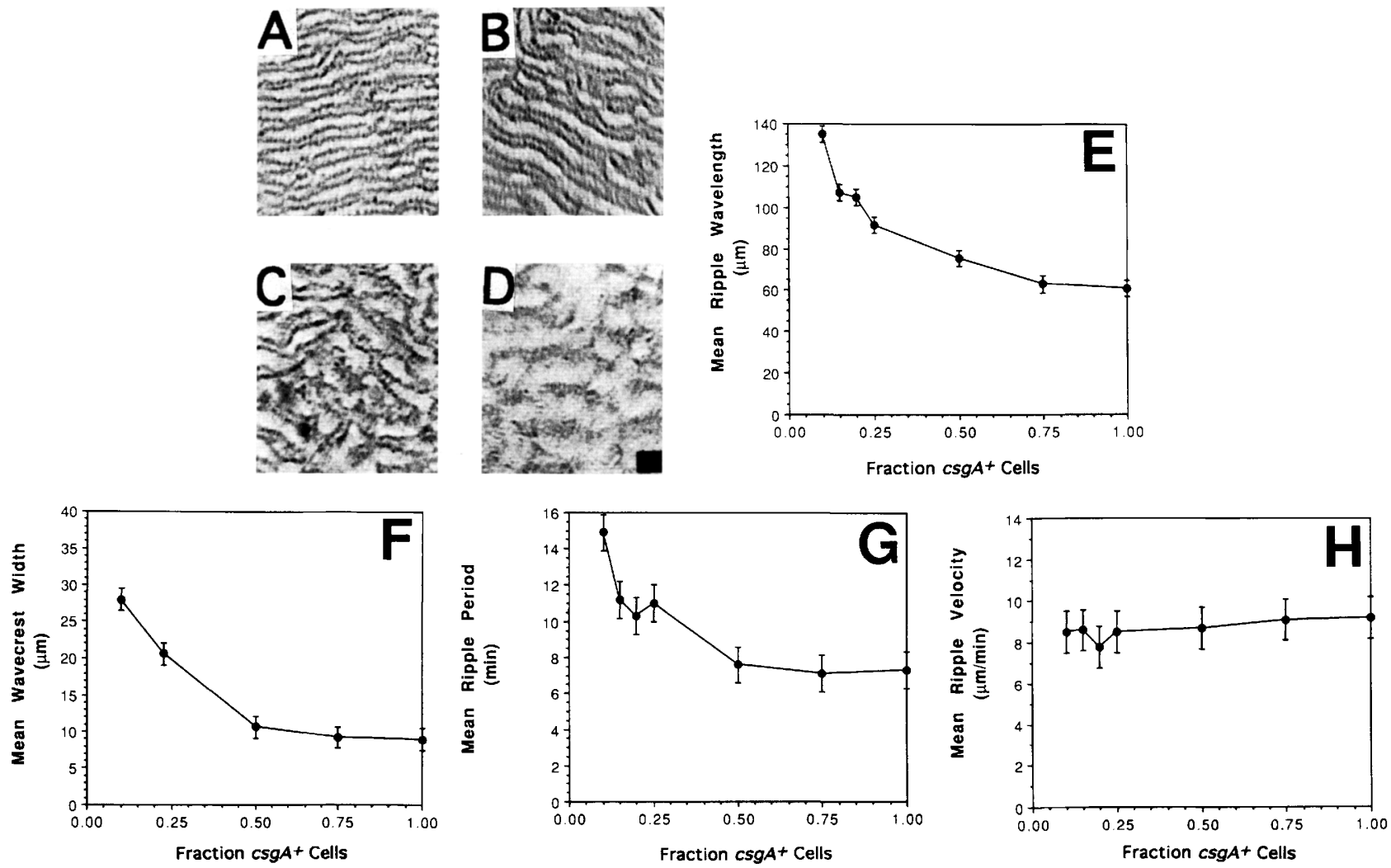

Figure 7. Dependence of ripple structure and dimension on the fraction of $\operatorname{csg} A^{+}$cells in mixtures with $\operatorname{csg} A$ mutants. Submerged cultures of rippling cells observed by bright-field microscopy after $48 \mathrm{hr}$ partial starvation. The total cell density of the starting culture was kept constant at $2 \times 10^{8}$ cells $/ \mathrm{ml} .|A| 100 \% \operatorname{csg} A^{+} ;(B) 50 \% \operatorname{csg} A^{+} ;(C) 25 \% \operatorname{csg} A^{+} ;(D) 10 \% \operatorname{csg} A^{+} ;(E)$ mean ripple wavelength vs. fraction $\operatorname{csg} A^{+}$cells; $(F)$ mean wavecrest width vs. fraction $\operatorname{csg} A^{+}$cells; $(G)$ mean ripple period vs. fraction $\operatorname{csg} A^{+} \operatorname{cells;}(H)$ mean ripple velocity vs. fraction $\operatorname{csg} A^{+}$cells. Objective magnification $(A-D)$ was $2.5 \times$. Scale bar, $100 \mu \mathrm{m}$. 
$10 \%$, the wavelength of the ripples lengthened to 140 $\mu \mathrm{m}$ (Fig. 7E), the wavecrest broadened to $30 \mu \mathrm{m}$ (Fig. 7F), and the period slowed to a mean of $15 \mathrm{~min}$ (Fig. 7G). Nevertheless, the phase velocity of the ripples remained a constant $8 \mu \mathrm{m} / \mathrm{min}$ (Fig. $7 \mathrm{H}$ ). The wavelength, wavecrest width, and ripple period varied nonlinearly with the fraction of $\operatorname{csg} A^{+}$cells. No ripples were observed when the fraction of $\operatorname{csg} A^{+}$cells was decreased to $<10 \%$ of the mixture.

Even though $\operatorname{csg} A^{-}$mutant cells are unable to produce C-factor, they are able to respond to it (Shimkets et al. 1983; Kim and Kaiser 1990a, 1990b). Pure cultures of $\operatorname{csg} A^{-}$cells are known to be incapable of rippling (Shimkets and Kaiser 1982). Nevertheless, the reversal hypothesis suggests that $\operatorname{csg} A^{-}$mutant cells might be found in the ripples because they should reverse when contacted by a $\operatorname{csg} A^{+}$cell (Fig. 3). To ascertain the locations of $\operatorname{csg} A^{-}$cells in rippling mosaics, $\operatorname{csg} A^{+}$(DK1622) and $\operatorname{csg} A^{-}$(LS202) cells were labeled separately with different fluorescent dyes. PKH-2, with an emission peak of $504 \mathrm{~nm}$, and PKH-26, with an emission peak of $570 \mathrm{~nm}$, were chosen (Sager and Kaiser 1993a). Separately labeled cells were mixed in various ratios and induced to develop on TPM agar (see Materials and methods). Both ripples and nascent fruiting bodies form at $7 \mathrm{hr}$ of development; ripples persist between fruiting bodies until at least $9 \mathrm{hr}$ of development.

The fluorescence emitted from the $1: 1$ mixture of $\operatorname{csg} A^{+}$and $\operatorname{csg} A^{-}$cells was scanned independently and simultaneously at the base of ripples by dual-channel fluorescence confocal microscopy (Fig. 8A,B). Both $\operatorname{csg} A^{+}$and $\operatorname{csg} A^{-}$cells were found oriented along the direction of wave propagation with their long axes aligned relatively parallel to one another, an arrangement similar to that detected in pure $\operatorname{csg} A^{+}$cultures (Fig. 2). Profiles of the fluorescence intensity revealed an eightfold variation from the base of the trough to the base of the crest of a ripple (Fig. 8, C and D), corresponding to an eightfold variation in cell density (Sager and Kaiser 1993a). The colocalization of the $\operatorname{csg} A^{+}$and $\operatorname{csg} A^{-}$cells agrees with the induced reversal hypothesis.

Similar profiles were obtained when the fluorescent markers used to tag each cell type were inverted /data not shown). Moreover, when $\operatorname{csg} A^{+}$cells were labeled with different fluorescent markers, mixed in a 1:1 ratio, and induced to ripple, the fluorescence distribution appeared identical (data not shown). Thus, neither fluorescent label appears to affect the rippling capacity of labeled cells. As the fraction of labeled $\operatorname{csg} A^{+}$cells in mosaic ripples was varied from $25 \%$ to $75 \%$, the relative number of $\operatorname{csg} A^{+}$cells detected in mosaic ripples was found to be directly proportional to the number of $\operatorname{csg} A^{+}$ cells induced to ripple, as expected. Moreover, as the fraction of $\operatorname{csg} A^{+}$cells was reduced to $10 \%$, fluorescence scans showed that the mean ripple wavelength expanded to a maximum of $140 \mu \mathrm{m}$, in agreement with videographic data (Fig. 7).

\section{Discussion}

A model for the propagation of traveling waves of developing Myxococcus cells is described in which end-to-end collisions between cells initiates $\mathrm{C}$-signaling, which in turn, increases the probability that individual cells reverse their direction of gliding. In a system of ripples, the average cell would move about one wavelength, collide
Figure 8. Fluorescence confocal microscopy at the base of $9-\mathrm{hr}$ ripples composed of a 1:1 mixture of PKH-2-labeled $\operatorname{csg} A^{+}$ (DK1622) and PKH-26-labeled $\operatorname{csg} A^{-}$ (LS202) cells. (A) Fluorescence intensity profile of $\operatorname{csg} A^{+}$cells; $(B)$ fluorescence intensity profile of $\operatorname{csg} A^{-}$cells. Scale bar, 20 $\mu \mathrm{m}$. (C) Calibrated gray-scale intensity scan of $\operatorname{csg} A^{+}$cells fluorescence shown in $A_{;}(D)$ calibrated gray-scale intensity scan of $\operatorname{csg} A^{-}$cells fluorescence shown in $B$. The ordinate scale in $C$ and $D$ is given in arbitrary fluorescence units.
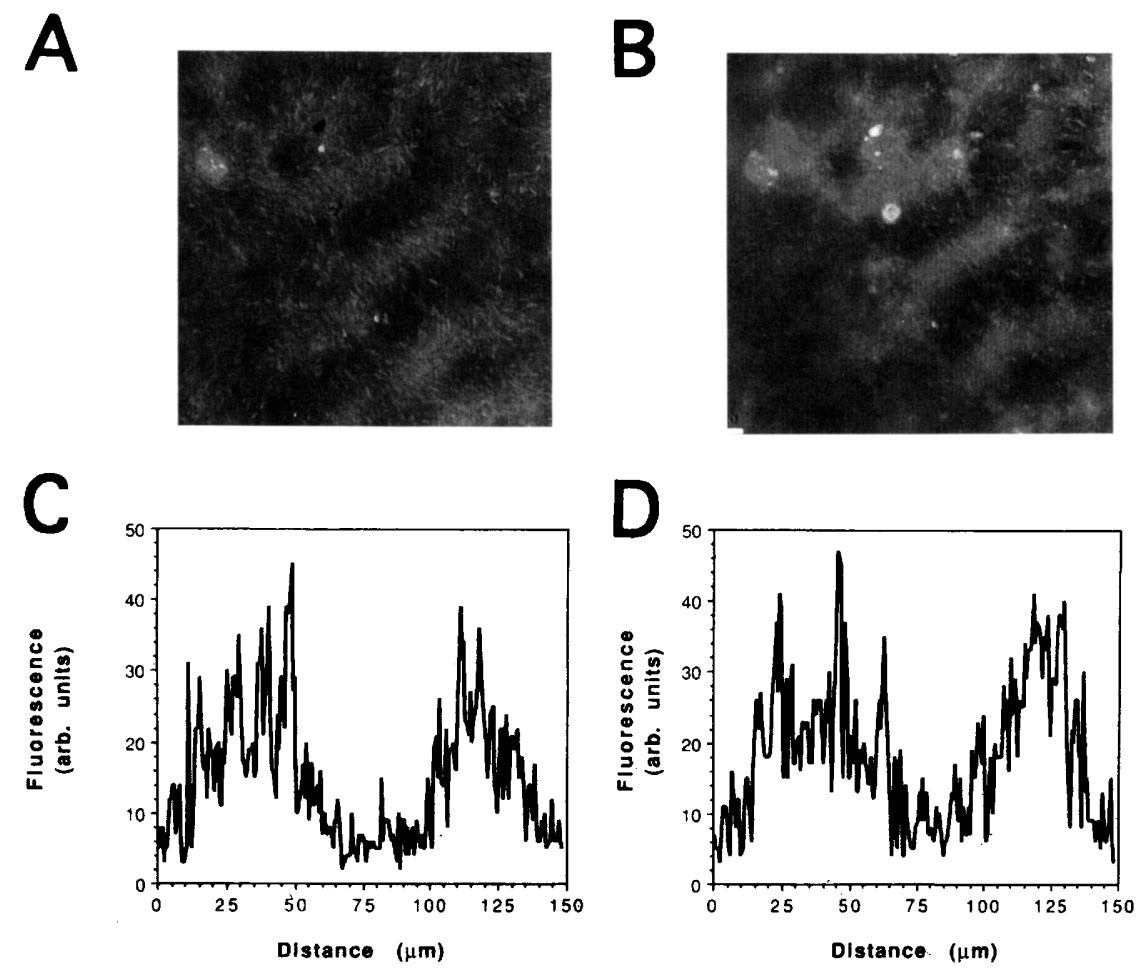
with another cell, and reverse. This model makes certain specific predictions that are tested here; it also gives a cell-molecular explanation for a number of otherwise puzzling observations. The model accounts for the absence of net transport of cells in long-term rippling cultures. If periodic C-signal transmission causes cells to oscillate repeatedly back and forth, there would be no net cell movement even after several days, as observed (Shimkets and Kaiser 1982). The model also accounts for the absence of constructive or destructive interference between counter-migrating waves, which are heaps of cells (Fig. 1), by substituting reflection for interpenetration of waves.

It is not proposed that C-signaling also accounts for the side-by-side alignment of cells in the traveling waves or for the lateral coordination of cell movement in these waves. These are likely to be directed by the products of the other genes that govern the density-dependent adventurous and social swarming behavior of Myхосоccus cells (Hodgkin and Kaiser 1977, 1979a,b; Kaiser and Crosby 1983; S. Wu and D. Kaiser, unpubl.). This view is based on the observation that agll, aglQ, aglB, aglG, tgl, and $s g l B$ mutant strains, which exhibit aberrant adventurous or social motility, cannot ripple (Shimkets and Kaiser 1982). Other experiments will be required to elucidate the molecular role of these genes and the nature of their cell interactions, which nevertheless are clearly indicated by their observed cell-density dependence (Kaiser and Crosby 1983).

It is known from studies of $\mathrm{C}$-factor-deficient mutants that C-factor is required for rippling (Shimkets and Kaiser 1982; Li et al. 1992). It has also been inferred from the failure of C-signaling in nonmotile cells (Kroos et al. 1988), and from the rescue of their C-signaling capability by mechanical alignment, that $\mathrm{C}$-signal transmission required a particular orientation of cells (Kim and Kaiser 1990c). Nonmotile cells were aligned by allowing them to settle into scratches in agar, and C-signal transmission was observed between cells in the scratches while at the same time there was no transmission between more randomly organized cells on the surface between scratches (Kim and Kaiser 1990c). In the model proposed here, it is specifically end-to-end cell contact that induces intercellular C-signaling. The mechanically aligned cells described above had end-to-end contacts, as well as the more common side-by-side contacts. Cells in ripples tend to be aligned perpendicular to the ripple crest (Fig. 2). Given that and the fact that cells glide in the direction of their long axis, the high density of cells within ripples $\left(10^{11}\right.$ cells $\left./ \mathrm{cm}^{3}\right)$ should ensure that endto-end contacts result from a meeting of two ripples.

It is proposed that one consequence of intercellular $\mathrm{C}$-signaling is to increase the frequency of reversal of cell gliding direction. It is shown here that addition of $\mathrm{C}$-factor to wild-type cells developing on agar results in a threefold-increased rate of reversal (Fig. 5). Larger doses of up to 0.08 unit did not increase the frequency and 0.16 unit inhibited cell movement. Bioassays carried out to monitor $\mathrm{C}$-factor purification revealed that $\operatorname{csg} A^{-}$cells were developmentally rescued in the 0.02 - to 0.08 -unit range of C-factor, but higher doses were inhibitory (Kim and Kaiser 1990a, 1990b, 1991). This nonlinearity was observed throughout a 1000-fold purification of the protein, and its basis is unknown. Because wild-type cells produce (by definition) 1 unit of $\mathrm{C}$-factor under standard assay conditions, exogenous $\mathrm{C}$-factor presented to $\operatorname{csg} A^{+}$ cells may have to compete with endogenous $\mathrm{C}$-factor in a nearly saturated signal transduction system. In any case, the inhibition of single cell movement by large doses of $\mathrm{C}$-factor is consistent with the observed inhibition of the developmental rescue of $\operatorname{csg} A^{-}$cells under similar conditions (Kim and Kaiser 1990a,b).

The movements of individual fluorescently labeled cells in ripples were tracked. In the simplest version of the model, cells in a ripple crest would all move in concert as a single cohort. It was observed, however, that cells spent some time in both ripple crests and troughs, so that the cellular composition of a wave would be expected to change progressively. Moreover, cells behaved in many different ways. Evidently cell behavior is not stereotyped; however, it is constrained in ways that conform to the model. Cells moved in linear tracks that paralleled the direction of ripple propagation. Approximately equal numbers of cells were observed to be moving in the direction of ripple propagation and in the counter direction. Cells reversed three times more frequently when they were situated in a wave than when present in an adjacent trough, clearly showing that the frequency of cell reversals is spatially regulated. Given a statistical framework, the model would predict a higher reversal frequency within a wave where cells had the opportunity to collide than between waves where opportunities would be fewer.

In a similar statistical context, the reversal model would predict that decreasing the probability of C-signaling should decrease the mean cell reversal frequency and thus increase the average distance a cell would travel before reversing. The consequence would be an extended wavelength. As expected, the mean wavelength of ripples is observed to increase progressively as the fraction of $\operatorname{csg} A^{+}$cells is decreased in mixtures with $\operatorname{csg} A^{-}$cells (Fig. 6). When two $\operatorname{csg} A^{+}$cells contact each other end to end, both cells would have their reversal probability increased by C-signal transmission (Fig. 3A). Similarly, when a $\operatorname{csg} A^{+}$cell contacts a $\operatorname{csg} A^{-}$cell, the $\operatorname{csg} A^{-}$cell should reverse. However, because $\operatorname{csg} A^{-}$cells fail to produce $\mathrm{C}$-factor, they cannot induce the reversal of the $\operatorname{csg} A^{+}$cells in contact with them. These unsignaled $\operatorname{csg} A^{+}$cells would be expected to continue to move in the same direction as the $\operatorname{csg} A^{-}$cells they recently stimulated to reverse. This would desynchronize the migration of $\operatorname{csg} A^{+}$and $\operatorname{csg} A^{-}$cells and might be expected to broaden and render the wavecrest more diffuse. The wavecrest width does expand fourfold and appears intermittently disrupted as the fraction of $\operatorname{csg} A^{+}$cells is reduced to $10 \%$ of the rippling cell population (Fig. 6). Because cells are $7 \mu \mathrm{m}$ long, on average (Kaiser 1979), approximately four cells lined end-to-end could be contained within a $30-\mu \mathrm{m}$-wide wave crest. As ripples with wider crest widths were not detected, the maxi- 
mum range of intercellular coordination of cells in a ripple wave may be limited to approximately four cell lengths.

Thus, the wavelength of a ripple is related to the average distance a cell travels before reversal, and the data show continuous variation in ripple wavelength from 60 to $140 \mu \mathrm{m}$ (Fig. 7E). The speed at which the ripple wave train appears to travel (its phase velocity) is independent of the ratio of $\operatorname{csg} A^{+} / \operatorname{csg} A^{-}$cells, having the constant value of $8 \mu \mathrm{m} / \mathrm{min}$ (Fig. $7 \mathrm{H}$ ). To travel $60 \mu \mathrm{m}$ before reversing, cells should reverse no more frequently than $0.13 \mathrm{times} / \mathrm{min}$, on average, whereas to travel $140 \mu \mathrm{m}$, cells should, on average, reverse no less frequently than $0.06 \mathrm{times} / \mathrm{min}$. Moreover, the mean reversal rates of cells tracked within ripples varies from 0.025 to 0.081 reversals/cell-min, as cells travel from troughs to crests (Fig. 6B). These calculations and observations imply that the range of $0.025-0.13$ reversals/cell-min is compatible with a stable ripple pattern. However, the single cell reversal rates of the constitutively reversing $\Omega 536$ and $\Omega 224 \mathrm{frzCD}-$ insertion strains lay outside of this frequency range and may account for their inability to ripple (Fig. 4).

The relation between rippling and fruiting body morphogenesis has been an enigma since the discovery of ripples (Reichenbach 1965). Rippling normally accompanies formation of fruiting bodies, and the two have similar dimensions: Ripple wavelengths range from 60 to $140 \mu \mathrm{m}$, depending on $\operatorname{csg} A^{+}$concentration (Fig. 7), and the $80-\mu \mathrm{m}$ mean diameter of a wild-type fruiting body falls inside this range (Sager and Kaiser 1993b). Both are absolutely dependent on C-signaling. Nevertheless, suppressed $\operatorname{csg} A$ mutants have been isolated that form fruiting bodies yet do not ripple (Rhie and Shimkets 1989). In submerged culture with MC7 buffer (Kuner and Kaiser 1982), wild-type cells develop into fruiting bodies but are seldom seen to ripple. Thus, rippling itself is not essential for fruiting body construction, at least as it is carried out in the laboratory. Nevertheless, the high density of cells in ripple crests (Fig. 8A) is comparable to that of the outer domain of the fruiting body (Sager and Kaiser 1993a). Moreover, in both ripple wave crests and in the outer domain of the fruiting body, cells appear highly aligned (Fig. 2; Sager and Kaiser 1993a). An architecture of regularly aligned cells and the resulting high cell density have been shown to promote efficient C-signaling (Kroos et al. 1988; Kim and Kaiser 1990c). Thus, rippling waves and the morphogenesis of fruiting bodies could both depend on the modulation of cell movement patterns by intercellular C-signaling. This modulation could be mediated by the cascade of Frz proteins that regulate reversal frequency (Fig. 4; Blackhart and Zusman 1985; McBride et al. 1989).

The precise way that movement is modulated is not likely to be the same in ripples and fruiting bodies, however. Different levels of C-signaling are required for each process (Kim and Kaiser 1991; Li et al. 1992) In the nascent fruiting body, cells move in circular streams (Sager and Kaiser 1993a). In ripples, the typical path of cell movement is linear. These differences in paths of cell migration may arise from the differences in the ways in which the cells are packed in the two structures. In ripples, cells are aligned with their long axes parallel, forming dense side-by-side arrays. Cells in these arrays are proposed to contact one another end to end, but only transiently as ripples collide. Thus, cells in ripples have opportunities to interact through extensive side-by-side contact with less extensive and periodic end-to-end contact. In contrast, within the ring-like outer domain of the fruiting body, whose average width is $35 \mu \mathrm{m}$, the cells are aligned end to end around a mean perimeter of 300 $\mu \mathrm{m}$ (Sager and Kaiser 1993a). These cells have many endto-end as well as side-by-side contacts $1 \mathrm{O}^{\prime}$ Connor and Zusman 1989; Kim and Kaiser 1990c; Sager and Kaiser 1993b). Thus, cells in the outer domain of the fruiting body have the opportunity for many more end-to-end interactions compared with those in ripples.

Experiments in this paper provide additional evidence that end-to-end intercellular contacts favor C-signal transmission. A and S motility appear to involve primarily side-by-side contacts or close side-by-side juxapositions of cells (Reichenbach 1965; Hodgkin and Kaiser 1977,1979a,b; Kaiser and Crosby 1983). We would suggest that the balance between end-to-end contact, which controls C-signaling, and cell density, which controls A and $\mathrm{S}$ motility, ultimately sets the pattern of cell movement for rippling or fruiting body construction.

\section{Materials and methods}

\section{Bacterial strains and strain construction}

Wild-type strain DK1622 was described previously /Kaiser 1979). LS202 is a derivative of DK1622, and contains the point mutation $\operatorname{csg} A-731$ (Hagen et. al 1978; Shimkets and Asher 1988), which confers a csg $A^{-}$developmental phenotype. Tn5lac $\Omega 536$ is inserted near the center of the frzCD gene and provides a transcriptional fusion to the promoter upstream of the gene (strain DZF3591; Weinberg and Zusman 1989). DK8505 was constructed by $\mathrm{Mx} 4$ transduction of $\mathrm{Tn} 5 \mathrm{lac}$ insertion $\Omega 536$ into DK 1622 . Tn $5 \Omega 224$ is inserted near the $3^{\prime}$ end of the frz $C D$ gene (strain DZF3460; McBride et al. 1989). DK8506 was constructed by $M x 4$ transduction of $\mathrm{Tn} 5$ insertion $\Omega 224$ into DK1622. Bacteria were grown at $32^{\circ} \mathrm{C}$ in CTT broth $[10 \mathrm{~g} /$ liter of casitone, 8 mM $\mathrm{MgSO}_{4}, 1 \mathrm{~mm}$ potassium phosphate, $10 \mathrm{~mm}$ Tris-HCL, final $\mathrm{pH}$ adjusted to 7.6 (Hodgkin and Kaiser 1977) ] to exponential growth phase.

\section{Spore counts}

Heat and sonication-resistant spores were measured in triplicate as described previously (Sager and Kaiser 1993b).

\section{C-factor purification}

$\mathrm{C}$-factor was purified as described previously (Kim and Kaiser 1990b). Briefly, developmentally wild-type strain DK5204 (Kroos et al. 1986) was conditioned on developmental agar and cells harvested at $16 \mathrm{hr}$ of development. Harvested cells were flash-frozen at $-80^{\circ} \mathrm{C}$ in MC7 buffer (Kuner and Kaiser 1982) at a density of $1.5 \times 10^{10}$ cells $/ \mathrm{ml}$. To purify C-factor, cells were passed through three freeze/thaw cycles and homogenized by use of sonication. The sonicate was centrifuged at $100,000 \mathrm{~g}$ for 
$1 \mathrm{hr}$, and the pellet resuspended in developmental buffer containing 1.2\% CHAPS. After $18 \mathrm{hr}$ of solubilization, the suspension was centrifuged at $100,000 \mathrm{~g}$ for $1 \mathrm{hr}$, and the supernatant was processed by ultrafiltration using a $10 \mathrm{kD}$ cutoff filter. The filtrate had an average sp. act. of $60 \mathrm{C}$-factor $\mathrm{U} / \mathrm{mg}$ of protein and was stable for at least 10 days at $4^{\circ} \mathrm{C}$. One $\mathrm{C}$-factor unit was previously defined by Kim and Kaiser (1990a, 1990b) as the amount of $\mathrm{C}$-factor necessary to restore $2 \times 10^{8} \mathrm{csg} A^{-}$cells in developmental culture to $\operatorname{csg} A^{+}$numbers of fruiting bodies $(250$ fruiting bodies) and spores $\left(2 \times 10^{6}\right.$ spores $)$. C-factor was further purified, by use of ion-exchange (mono Q) chromatography, to a sp. act. of $400 \mathrm{C}$-factor $\mathrm{U} / \mathrm{mg}$ of protein. This activity was stable for at least $24 \mathrm{hr}$ at $4^{\circ} \mathrm{C}$.

\section{Antibody neutralization of C-factor activity}

Affinity-purified polyclonal antibody to a $\operatorname{csg} A-l a c Z$ protein fusion was a gift from H. Kimsey (Tufts Medical School, Boston, MA). To neutralize C-factor activity, a dilute suspension of antibody was incubated with $\mathrm{C}$-factor containing extract for $5 \mathrm{hr}$ at $4^{\circ} \mathrm{C}$.

\section{Single-cell motility assay}

Wild-type cells (strain DK5204) were grown in 1\% CTT buffer to mid-exponential phase and resuspended at a density of $5 \times 10^{8}$ cells $/ \mathrm{ml}$. This suspension $(700 \mu \mathrm{l})$ was placed in a tissue-culture chamber well (Nunc Lab Tek four-well chamber) and cells were developed at $32^{\circ} \mathrm{C}$ for $48 \mathrm{hr}$ as described previously (Sager and Kaiser 1993b). For microscopy, the tissue-culture chamber was encased within a custom-designed stage micrometer drive, which allowed examination of the same field of cells before and after addition of sample. Prior to addition of sample, a field of cells were observed by bright-field microscopy and videographed as described previously (Sager and Kaiser 1993a). Cells were examined if they were found within a region $<50 \mu \mathrm{m}$ from the perimeter of a fruiting body. The same cells were examined $20 \mathrm{~min}$ after sample addition. The motility patterns of at least 20 cells were monitored for an average time of 2 min, yielding at least 500 cell-frames of data, and the mean reversal frequencies determined from triplicate independent experiments were averaged for each datum.

\section{Rippling assay}

For submerged culture analyses, growing DK1622 and LS202 cells were mixed in various proportions and resuspended at a density of $5 \times 10^{9}$ cells $/ \mathrm{ml}$. This suspension $(25 \mu \mathrm{l})$ was added to $375 \mu$ l of CTT buffer (Hodgkin and Kaiser 1977), and cells were grown in submerged culture in a multiwell tissue-culture chamber (Falcon 3047). After incubation at $32^{\circ} \mathrm{C}$ for $22 \mathrm{hr} 1 \%$ CTT culture buffer was replaced with $400 \mu \mathrm{l}$ of MC7 buffer (Kuner and Kaiser 1982) containing $0.25 \%$ (wt/vol) casitone (Difco Laboratories, Detroit, MI). Cells were incubated for an additional 24 $\mathrm{hr}$ at $32^{\circ} \mathrm{C}$, at which time pronounced ripples were visible. Ripples were stable for at least 4 days at $32^{\circ} \mathrm{C}$. Cells rippling in submerged culture were recorded by time-lapse videography using a Leitz inverted microscope as described previously (Sager and Kaiser 1993a).

\section{Fluorescence confocal microscopy}

For analyses of ripple mixtures moving on an agar surface, growing DK1622 and LS202 cells were labeled separately with lipophilic fluorescent dyes as described (Sager and Kaiser 1993a), mixed in various proportions, and resuspended in TPM buffer
(Kroos et al. 1986) to a density of $5 \times 10^{9}$ cells $/ \mathrm{ml}$. Aliquots $(25$ $\mu$ l) were spotted onto TPM agar-coated slides (Sager and Kaiser 1993a). Upon incubation for $8 \mathrm{hr}$ at $32^{\circ} \mathrm{C}$, ripples were present between nascent aggregates. Ripples were stable for $2-3 \mathrm{hr}$ at $32^{\circ} \mathrm{C}$. Cells rippling on TPM agar were analyzed at $20 \times$ in an upright fluorescence confocal microscope using Phoibos 1000 imaging software from Molecular Dynamics (Sunnyvale, CA) as described previously (Sager and Kaiser 1993a). Dual-channel fluorescence confocal microscopy was performed as described previously (Sager 1994). To calibrate and separate the fluorescence intensity levels of each channel, a pair of calibration equations were applied to every pixel in the confocal scans. Specifically, for each pixel, Channel $1_{\text {output }}=\left[\left(1.00 \times\right.\right.$ Channel $\left.1_{\text {input }}\right)-(0.36$ $\times$ Channel $\left.\left.2_{\text {input }}\right)\right]$, while Channel $2_{\text {output }}=[(1.94 \times$ Channel $\left.2_{\text {input }}\right)-\left(0.03 \times\right.$ Channel $\left.\left.1_{\text {input }}\right)\right]$.

\section{Time-lapse fluorescence confocal videomicroscopy}

Time-lapse videomicroscopy was performed using a laser-scanning confocal microscope system designed by Dr. Steven Smith (Cell Sciences Imaging Facility of Stanford University, CA). Cell positions were recorded by time-lapse videomicroscopy every $30 \mathrm{sec}$. Laser power was set to $12.5 \%$ of maximum. Data analysis was performed using National Institutes of Health (NIH) Image Software, version 1.54 .

\section{Acknowledgments}

We thank Alfred Spormann for assistance with C-factor purification, Harvey Kimsey for his gift of anti-csgA antibody, Hans Reichenbach and Seung Kim for helpful discussions, and Mark McBride and David Zusman for frz strains. We thank Drs. Chris Mohr, Rick Roberts, and Frank Slack for critical review of this manuscript. The Hasselblad Foundation provided optical equipment. B.S. was supported by predoctoral U.S. Public Health Service grant GM 07599-14. Research was supported by U.S. Public Health Service research grant GM23441 to DK.

The publication costs of this article were defrayed in part by payment of page charges. This article must therefore be hereby marked "advertisement" in accordance with 18 USC section 1734 solely to indicate this fact.

\section{References}

Blackhart, B.D. and D.R. Zusman. 1985. "Frizzy" genes of Myxococcus xanthus are involved in control of frequency of reversal of gliding motility. Proc. Natl. Acad. Sci. 82: 87678770.

Burchard, R.P. 1981. Gliding motility of prokaryotes: Ultrastructure, physiology, and genetics. Annu. Rev. Microbiol. 35: 497-529.

De Felici, M., S. Dolci, and M. Pesce. 1992. Cellular and molecular aspects of mouse primordial germ cell migration and proliferation in culture. Int. I. Dev. Biol. 36: 205-213.

Gill, R.E., and L.J. Shimkets. 1993. Genetic approaches for analysis of bacterial behavior. In Myxobacteria II (ed. M. Dworkin and D. Kaiser|, pp. 129-155. American Society for Microbiology, Washington, D.C.

Hagen, T.J. and L.J. Shimkets. 1990. Nucleotide sequence and transcriptional products of the csg locus of Myxococcus xanthus. I. Bacteriol. 172: 15-23.

Hagen, D.C., A.P. Bretscher, and D. Kaiser. 1978. Synergism between morphogenetic mutants of Myxococcus xanthus. Dev. Biol. 64: 284-296.

He, Q., H.-W. Chen, A. Kuspa, Y. Cheng, D. Kaiser, and L.J. 
Shimkets. 1994. A physical map of the Myxococcus xanthus chromosome. Proc. Natl. Acad. Sci. 91: (in press).

Heberlein, U., T. Wolff, and G.M. Rubin. 1993. The TGF $\beta$ homolog $d p p$ and the segment polarity gene hedgehog are required for propagation of a morphogenetic wave in the Drosophila retina. Cell 75: 913-926.

Hodgkin, J. and D. Kaiser. 1977. Cell-cell stimulation of movement in nonmotile mutants of Myxococcus. Proc. Natl. Acad. Sci. 74: 2938-2942.

- 1979a. Genetics of gliding motility in Myxococcus xanthus (Myxobacterales): Genes controlling movements of single cells. Mol. \& Gen. Genet. 171: 167-176.

- 1979b. Genetics of gliding motility in Myxococcus xanthus (Myxobacterales): Two gene systems control movement. Mol. \& Gen. Genet. 171: 177-191.

Kaiser, D. 1979. Social gliding is correlated with the presence of pili in Myxococcus xanthus. Proc. Natl. Acad. Sci. 76: 59525956.

Kaiser, D. and C. Crosby. 1983. Cell movement and its coordination in swarms of Myxococcus xanthus. Cell Motil. 3: 227-245.

Keller, R. and R. Winklbauer. 1992. Cellular basis of amphibian gastrulation. Curr. Top. Dev. Biol. 27: 39-89.

Kim, S.K. 1992. "Regulation of Myxococcus xanthus development by C-factor, an intercellular signaling protein." Ph.D. thesis, Stanford University, Stanford, CA.

Kim, S.K. and D. Kaiser. 1990a. C-factor: A cell-cell signaling protein required for fruiting body morphogenesis of $M$. xanthus. Cell 61: 19-26.

-1990b. Purification and properties of Myxococcus xanthus C-factor, an intercellular signaling protein. Proc. Natl. Acad. Sci. 87: 3635-3639.

-1990c. Cell alignment required in differentiation of Myxococcus xanthus. Science 249: 926-928.

. 1991. C-factor has distinct aggregation and sporulation thresholds during Myxococcus development. I. Bacteriol. 173: 1722-1728.

Kim, S.K., D. Kaiser, and A. Kuspa. 1993. Control of cell density and pattern by intercellular signaling in Myxococcus development. Annu. Rev. Microbiol. 46: 117-139.

Kingsley, D.M. 1994. What do BMPs do in mammals? Clues from the mouse short-ear mutation. Trends Genet. 10: 1621.

Kroos, L. and D. Kaiser. 1987. Expression of many developmentally regulated genes in Myxococcus xanthus depends on a sequence of cell interactions. Genes \& Dev. 1: 840-854.

. 1993. Intercellular signaling. In Myxobacteria II /ed. M. Dworkin and D. Kaiser), pp. 257-283. American Society for Microbiology. Washington, D.C.

Kroos, L., A. Kuspa, and D. Kaiser. 1986. A global analysis of developmentally regulated genes in Myxococcus xanthus. Dev. Biol. 117: 252-266.

Kroos, L., P. Hartzell, K. Stephens, and D. Kaiser. 1988. A link between cell movement and gene expression argues that motility is required for cell-cell signaling during fruiting body development. Genes \& Dev. 2: 1677-1685.

Kuner, J.M. and D. Kaiser. 1982. Fruiting body morphogenesis in submerged cultures of Myxococcus. I. Bacteriol. 151: 458461.

Le Douarin, N.M. 1984. Cell migrations in embryos. Cell 38: 353-360.

Li, S.-F., B.-U. Lee, and L.J. Shimkets. 1992. csgA expression entrains Myxococcus xanthus development. Genes \& Dev. 6: 401-410.

Ma, C., Y. Zhou, P.A. Beachy, and K. Moses. 1993. The segment polarity gene hedgehog is required for progression of the morphogenetic furrow in the developing Drosophila eye. Cell 75: 927-938.

McBride, M.J., R.A. Weinberg, and D.R. Zusman. 1989. Frizzy aggregation genes of the gliding bacterium Myxococcus xanthus show sequence similarity to the chemotaxis genes of enteric bacteria. Proc. Natl. Acad. Sci. 86: 424-428.

O'Connor, K.A. and D.R. Zusman. 1989. Patterns of cellular interactions during fruiting-body formation in Myxococcus xanthus. J. Bacteriol. 171: 6013-6024.

- 1991a. Behavior of peripheral rods and their role in the life cycle of Myxococcus xanthus. I. Bacteriol. 173: 33423355.

- 1991b. Development in Myxococcus xanthus involves differentiation into two cell types, peripheral rods and spores. J. Bacteriol. 173: 3318-3333.

Reichenbach, H. 1965. Rhythmische vorange bei der schwarmentfaltung von Myxobacterien. Ber. Dtsch. Bot. Ges. 78: $102-105$.

- 1980. Stigmatella aurantiaca (Myxobacterales) -Schwarmentwicklung und Fruchtkörperbildung. Film E 2421. Institute für den Wissenschaftlichen Film. Göttingen, Germany.

Rhie, H.G. and L.J. Shimkets. 1989. Developmental bypass suppression of Myxococcus xanthus $\operatorname{csg} A$ mutations. I. Bacteriol. 171: 3268-3276.

Rosenberg, E. 1984. Myxobacteria, development and cell interactions. Springer-Verlag, New York.

Russo-Marie, F., M. Roederer, B. Sager, L.A. Herzenberg, and D. Kaiser. 1993. Beta-Galactosidase activity in single differentiating bacterial cells. Proc. Natl. Acad. Sci. 90: 8194-8198.

Sager, B. 1994. "Spatially-restricted cellular differentiation during morphogenesis of the Myxococcus xanthus fruiting body." Ph.D. Thesis, Stanford University, Stanford, CA.

Sager, B. and D. Kaiser. 1993a. Two cell-density domains within the Myxococcus xanthus fruiting body. Proc. Natl. Acad. Sci. 90: 3690-3694.

- 1993b. Spatial restriction of cellular differentiation. Genes \& Dev. 7: 1645-1653.

Shimkets, L.J. 1984. Nutrition, metabolism, and the initiation of development. In Myxobacteria: Development and cell interactions. (ed. E. Rosenberg), pp. 91-107. Springer-Verlag, New York.

Shimkets, L.J., and S.J. Asher. 1988. Use of recombination techniques to examine the structure of the csg locus of Myxococcus xanthus. Mol. \& Gen. Genet. 211: 63-71.

Shimkets, L.J. and D. Kaiser. 1982. Induction of coordinated cell movement in Myxococcus xanthus. J. Bacteriol. 152: 451461.

Shimkets, L.J. and H. Rafiee. 1990. CsgA, an extracellular protein essential for Myxococcus xanthus development. J. Bacteriol. 172: 5299-5306.

Shimkets, L.J., R.E. Gill, and D. Kaiser. 1983. Developmental cell interactions in Myxococcus xanthus and the spoC locus. Proc. Natl. Acad. Sci. 80: 1406-1410.

Weinberg, R.A. and D.R. Zusman. 1989. Evidence that the Myxococcus xanthus frz genes are developmentally regulated. J. Bacteriol. 171: 6174-6186.

Wozney, J.M. 1992. The bone morphogenetic protein family and osteogenesis. Mol. Rep. Dev. 32: 160-167.

Zusman, D.R. 1982. "Frizzy" mutants: A new class of aggregation-defective developmental mutants of Myxococcus xanthus. I. Bacteriol. 150: 1430-1437. 


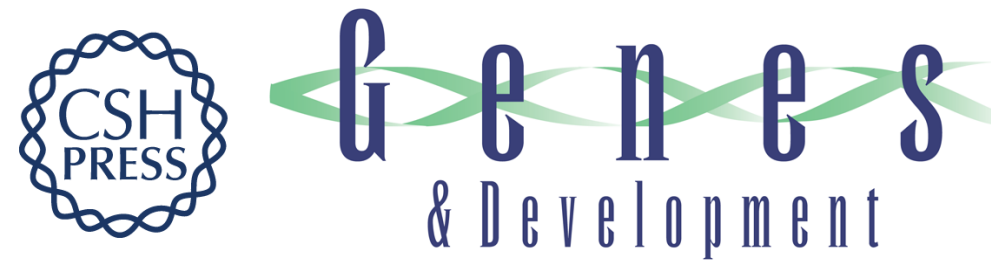

\section{Intercellular C-signaling and the traveling waves of Myxococcus.}

B Sager and D Kaiser

Genes Dev. 1994, 8:

Access the most recent version at doi:10.1101/gad.8.23.2793

References This article cites 41 articles, 24 of which can be accessed free at: http://genesdev.cshlp.org/content/8/23/2793.full.html\#ref-list-1

License

Email Alerting Service

Receive free email alerts when new articles cite this article - sign up in the box at the top right corner of the article or click here.

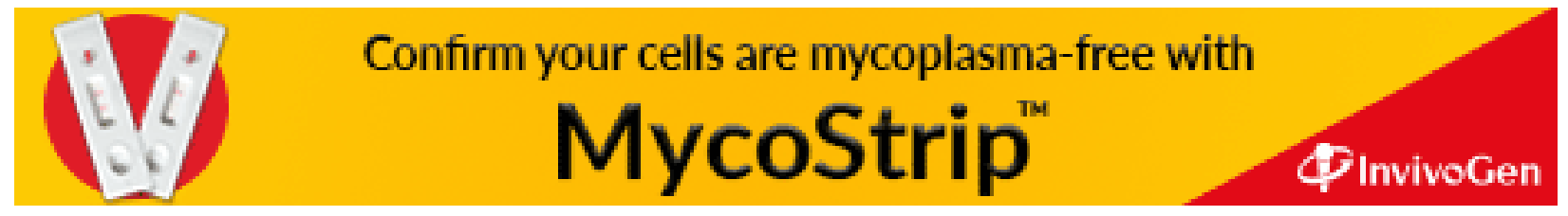

